\title{
Eighty years of composites reinforced by flax fibres: A historical review
}

\author{
Baley Christophe ${ }^{1}$, Bourmaud Alain ${ }^{1,{ }^{*}}$, Davies Peter ${ }^{2}$
}

1 Univ. Bretagne Sud, UMR CNRS 6027, IRDL, F-56100 Lorient, France

2 IFREMER, Centre de Bretagne, Marine Structures Laboratory, BP70, 29280 Plouzané, France

* Corresponding author : Alain Bourmaud, email address : alain.bourmaud@univ-ubs.fr

\begin{abstract}
:
The last 80 years have seen significant changes in industrial technologies, with the development of composite materials being particularly striking. These were hardly present before the Second World War but were made possible by the availability of new polymers, fibre reinforcements and innovative manufacturing techniques. In parallel, the traditional flax farming practices for the textile industry have benefited from major improvements in seed selection, retting and fibre extraction methods. This aims of this paper are twofold; first to describe the early work to develop flax fibre reinforced composites and compare their mechanical properties with those of contemporary flax fibres. And second, to understand the impact of significant efforts made recently to improve flax fibre production. The simple substitution of synthetic fibres is no longer sufficient to justify their use; their environmental benefits must be demonstrated, through life cycle analyses to support sustainable societal choices, and these are also discussed.
\end{abstract}

\section{Highlights}

- The first aircraft structural composite components were reinforced with flax in 1940. Flax fibres were used with adapted composite technologies (preg, untwisted fibres...). The flax potential to reinforce polymers was already demonstrated in 1940. Over the past 80 years, flax varieties and fibre yields have changed significantly. However, the geometry and mechanical properties of the fibres have remained stable.

Keywords : A. Natural fibres, A. Biocomposites, C. Micro-mechanics, D. Mechanical properties 


\section{Introduction}

Plant fibres have been used for centuries. These include flax, hemp and jute among others, but the present paper will be limited to textile flax fibres (linum usitatissimum L.). Even if the use of straw to reinforce mud in bricks is older, the earliest traces of human use of flax fibres for textile applications are some 36,000 years old [1]. There is currently considerable interest in the use of flax fibres to reinforce polymers but this is not a new idea. Indeed, in 1939, De Bruyne et al. [2] described development work on exactly such materials for primary aircraft structures. It is therefore interesting today to take a step back and consider the reasons which led to those early developments, the manufacturing processes used and the properties obtained, and to compare them to the biocomposites currently being developed. This allows us to place our current technology in context. First, a historical background to the use of flax fibres in polymer matrix composites will be presented. An analysis of the properties of those materials will then be discussed. Based on the results, a comparison will be made with the geometry and properties of fibres being proposed for composite reinforcement today. Changes in flax fibre production methods, including seed selection, retting methods and agricultural practices will then be discussed. Finally, the various arguments in favour of using flax rather than glass fibre reinforcement will be presented. The aims of the paper are twofold: First, to learn from early work to develop structural plant fibre composite components. That work is not well-known, but it addressed many of the questions being asked of these materials today. Inverse analysis will be used here to examine how mechanical properties have changed in 80 years. And second, to help to understand the impact of significant efforts made in recent years to improve flax fibre production through varietal selection and automation. Changes in agricultural practices and their effects on fibre properties will also be discussed.

\section{1937-1941. First structural applications of flax fibres as reinforcement in aeronautical} composites.

\subsection{Context and first developments}

Material developments frequently respond to particular requirements, depending not only on the scientific or technological needs but also on the availability and industrial development of raw materials. For example, for the first telegraph cables in the 19th century, electrical insulation was based on rubber coatings, waxed paper, glass and ceramics. But by the end of the century the demand for electricity was such that alternatives were needed, [3]. In 1906, the invention of Bakelite (based on the phenolformaldedyde reaction) provided a synthetic polymer, which could be applied first as a varnish then later as a matrix for paper or fabric composites. In 1917, this material was used for non-electrical applications, 
an example being an automotive gear stick handle (Rolls Royce 1917 model) [3]. In the composite sector, in the 1930's, the development of composites of cotton fabric impregnated by phenolic resin (Tufnol®) allowed the design of mechanical parts such as gears to be machined, and led to applications including marine transmission components [3]. At the start of the Second World War, this type of material (Kraft paper impregnated by phenolic resin) was used to manufacture components for 12 bomber planes, due to aluminium alloy supply shortages. Six of the planes which spent the winter in Africa showed cracks near rivets, whereas those which had stayed in England, exposed to rain and snow, showed signs of swelling and warping. At the time, metal/wood assemblies were common, but the latter is sensitive to changes in humidity. De Bruyne considered this behaviour and, in 1937, published results from his work on cotton reinforced phenolic composites [4] which he named Cord Aerolite. Then, in 1939, he published innovative results on flax/phenolic composites, referred to as Gordon Aerolite [2]. One of the initial aims of this work was to develop moulded variable pitch aircraft propellers for Haviland [5]. Norman de Bruyne, was a pioneer in the area of plant fibre composites and composite materials for structural applications. He founded the Cambridge Aeroplane Company in 1931, which became Aero Research Limited in 1934. Many authors consider his work to signal the start of the use of composites for structural applications [3][6][7][8].

\subsection{Lessons from early work on the use of flax fibres in structural composites.}

\subsubsection{New composite materials}

In his 1937 publication, De Bruyne covered many topical questions, sometimes still debated today in the scientific community, [4]. These included the selection of plant fibres, the behaviour of regenerated cellulose fibres (viscose), the influence of humidity on their mechanical properties, the influence of twist on fibre strength, and the consequences of the mesostructure of a unidirectional composite for mechanical performance. Other subjects treated included the influence of compaction pressure on properties (in tension, compression and shear), the influence of geometrical defects, energy absorption, fatigue behaviour, resistance to aging under different environmental conditions (rain, seawater, temperature and fire), and assembly by adhesive bonding. In order to improve mechanical properties (Table 1), cotton was replaced by flax fibres [2]. Flax fibres show significantly better performance [9], even though their lengths and diameters are similar; flax fibres have a lower microfibril angle (MFA, orientation of microfibrils with respect to the fibre axis), $20-30^{\circ}$ for cotton and only $10^{\circ}$ for flax. This MFA is inversely correlated with elementary fibre mechanical properties [9][10]. Moreover, the twist of cotton trichomes is not beneficial for mechanical behaviour, especially at low strain. A special machine was developed to 
manufacture unidirectional preimpregnated flax/phenolic strips [2]. This included orientation of fibres without twist [11], an impregnation bath and a drying operation. Composites were then manufactured by transverse compression at high pressure and temperature. It was found that the control of impregnation and fibre content was critical. For low fibre content, fibre swelling occurred, while if the fibre content was too high then low shear properties were obtained and machining was difficult. It should be noted that the use of a phenolic matrix with hydrophilic fibres can cause problems as the matrix cures by a condensation reaction, creating water vapour [5]. Other information from this work revealed that the authors were starting to develop the theory of fibre reinforcement and to recognize the importance of close control of moulding conditions; the objective of these trials was to understand how to characterize these new materials [6], to study assembly methods and more generally to start 'thinking composites'.

\subsubsection{Demonstrator manufacture}

In 1940, fears for aluminium shortages led to the UK Air Ministry passing a contract to Aero Research Limited in Duxford [12]. The first order for a prototype component with this new material technology was for a wing spar 30 feet long $(9.15 \mathrm{~m})$ for the Bristol Blenheim fighter-bomber. The design was based on the internal structure of the wing bone of a vulture (Figure 1) [13]. Other prototypes produced at the start of the war by Gordon Aerolite were a cockpit and a fuselage (Figure 2) for the Supermarine Spitfire $[13][11][12]$. At that time, the lack of suitable adhesives to bond the Aerolite resulted in joining of composite panels to the metallic structure with rivets, producing a patchwork similar to a boat hull. Later, in 1942, appropriate polymer adhesives were introduced, known as 'Redux' for Research at Duxford, with the development of phenol formaldehyde resins by De Bruyne [14]. Although many photos of the fuselage construction exist, no composite Spitfire was used in service. The production process was not optimized, the composite fuselage weight was the same as that of the conventional aluminium alloy [12], but this showed the potential of this new range of materials. This innovative programme was stopped by the British government in 1941 [3]. There were disagreements over the capacity to mould a fuselage panel in a single operation with low pressure. This was later achieved by Gordon and his team in 1951 [3], for a E10/47 delta wing using asbestos reinforced phenolic. Tests on cellulose fibres at the RAE (Royal Aircraft Establishment) in Farnborough ended in 1946. At that time, the potential of glass fibres was being evaluated for primary aircraft structures, even though the specific stiffness of glass fibres was around half that of flax fibres. However, the glass fibre/phenolic interface strength was found to be too low for high performance composites [6].

\section{Has the performance of flax fibre reinforcement changed since 1939 ?}


Table 1 presents the mechanical properties of unidirectional flax reinforced composites (tension, compression and shear) documented by De Bruyne in 1937-1939, together with recent published test results $[4][2][15][16][17][18][19][20][21][22][23]$.

Analysis of the composite mechanical properties in Table 1.

- First, it is interesting to note that there has been no significant improvement in the performance of unidirectional flax composites since 1939; the property values are of the same order of magnitude today. Despite slightly different matrix polymers, a very close correlation is observed for the modulus of UD composites (Fig 3.A); the literature shows that the stiffness of UD composites is mainly influenced by that of the fibres, which explains the linearity of this curve; it also underlines the stability of the stiffness of the flax fibres, estimated here at about $60 \mathrm{GPa}$, whatever the batch or the period considered. Results are different for the strength (Fig 3.B) which show more scatter. Composite strength depends on the modulus of the fibres but it is also strongly influenced by their individualization (thus by the retting and extraction parameters), the manufacturing parameters of the composites (drying, pressure, temperature), the fibre volume fraction and by the quality of the fibre-matrix interface (here the matrix polymers are different).

- The results published in 1939 describe very high fibre volume fractions (70 to $75 \%$ ), due to the very high forming pressures applied. However, the accurate measurement of flax fibre content is not straightforward [24], so we do not know how accurate these fibre volume fractions are.

- Characterization methods have improved since 1939, (accumulated experience on composites resulting in new test standards, improved load cells and extensometers). Compression testing in particular has been extensively studied [25] [26].

- There is no information on how the processing parameters used by De Bruyne affected the fibre cell walls and this may have a significant impact. Chemical treatments of fibres can improve certain mechanical properties of composites. For example, Bos et al. [16] used extraction in ethanol to remove the wax layer then impregnate the fibre cell walls with melamine formaldehyde (MF). This treatment reduces tensile strength but increases compression strength of unidirectional composites. We do not know whether De Bruyne treated the flax fibres, nor whether the resin penetrated the cell walls [2]. Also, temperature exposure during a process, due to thermoset crosslinking or thermoplastic polymer melting, may induce a significant drop in strength and stiffness of plant fibres $[27][28]$. 
- Fibre bundle separation can increase unidirectional composite tensile strength [29]. We have no information on this parameter.

- Flax composites show non-linear behaviour [30] and the values obtained depend on the strain range considered. No details are available here.

- Finally, the data available are limited to quasi-static properties. For structural applications, a more extensive characterization would be necessary, including the effects of moisture and cyclic loads.

\section{Changes in fibre production, properties and developement of preforms over a century}

\subsection{Flax fibre production}

Source of flax fibres: There is little information on the flax used by De Bruyne in 1939-1941 for the first composite structures, but it is most likely that it came from Ireland. The choice of flax as a reinforcement to replace cotton was suggested to De Bruyne by a Mr Malcolm Gordon (hence the name GordonAerolite) who had connections with an Irish linen mill in Belfast [8]. In England, in 1939, the cultivated land was only 1,200 hectares, whereas in Ireland 18,600 hectares were farmed in 1940 [31]. By comparison, in France in 1939, 48,300 hectares were used for flax and 31,000 hectares in Belgium in 1938. A significant effort by the British government for the war effort resulted in 15,600 hectares cultivated in England in 1942, and 25,000 in 1944. After the war, the financial incentives were reduced then removed completely and the production of flax in England dropped and almost disappeared (1,000 hectares in 1957) [31].

Fibre yields: The area of cultivated land gives only a first indication of agricultural activity; a more important indicator is the volume of fibres available for industrial applications (textile, paper, composite...), i.e. the fibre yield. However, there is a potential for production which can differ from the reality, according to the geographical area considered. The yield depends on the expertise of the farmer, the growing conditions, farming practices and the quality of seeds. In 1871, on experimental plots, the production of flax fibres could reach $1,175 \mathrm{~kg}$ per hectare [32]. In practice, the mean yield per hectare between the first and second world wars was only around $530 \mathrm{~kg}$ of fibres [31] and varied from $127 \mathrm{~kg}$ (England, 1920) to $510 \mathrm{~kg}$ (Ireland, 1912) (Table 2). So these yields are not very high with respect to the potential of the plant. To fully understand these historical data, it is also necessary to know in detail the fraction of fibres accounted for. The fibre yield is based only on the weight of long flax yarn, and the weight of short fibres, which do not have the same commercial value, should also be added. The former are assemblies of parallel fibre bundles whose length is that of the plant stem, while the latter are shorter non-parallel fibre bundle assemblies. Today, the aim is to reach a yield of 7,500 $\mathrm{kg}$ per hectare of straw 
(the total plant biomass that is delivered to the scutching factory before fibre extraction) [33], corresponding to an optimal fibre yield of $2,775 \mathrm{~kg}$ per hectare, with the fibres representing around $37 \%$ by weight of the biomass harvested after retting.

Table 3 below shows published examples of the different components of straw [33][34][35]. There has thus been considerable progress in fibre yields in recent years, thanks in particular to variety selection work, and that is continuing. For more information, the increase in biomass production between 1930 and now was discussed by Goudenhooft et al. [36]. Between 1990 and 2013, progress in genetic engineering resulted in an average gain of $32 \mathrm{~kg}$ of fibres per hectare per year (i.e. $2.3 \%$ per year) excluding improvements in crop protection techniques [33]. As an example, recent varieties (such as Elixir from Terre de lin) show a fibre yield improvement greater than $25 \%$ (25\% of the weight of retted stems before beating, i.e . including seeds), or $46 \%$ after beating (without the seeds) [37]. The aims of varietal selection, whatever its origin, have always been to increase the fibre production [38], the resistance to disease [39] and the lodging stability [40].

Seeds: The nature and the quality of seeds for flax textile production are very important parameters. The main controls performed on seeds are:

- The purity of the variety (genetic uniformity is essential; the farmer wants to grow a specific variety). It should be recalled that commercial seed varieties are certified and protected (intellectual property protection for 20 years). This provides a guarantee of tracability and quality.

- Sanitary quality (to avoid spreading disease).

- Seed germination rate. Farmers use seed planting equipment which accurately controls the number of seeds per $\mathrm{m}^{2}$. For textile flax, the aim is to reach 1,500 to 1,800 viable plants per $\mathrm{m}^{2}$. This number affects the fibre yield, the mechanical properties of the fibres, and the mechanical stability [41]. For oil seed flax (specific varieties of the same Linum usitatissimun L. plant), the aim is to optimize the quantity of seeds. In this case the plant density is 350 to 450 plants $/ \mathrm{m}^{2}$.

Before 1914, Russian seeds were the most popular, but there was a shortage after the First World War. In Belfast, the Linen Industry Research Association (L.I.R.A) organised the production and verification of seeds. Through repeated selection high quality seeds were developed and commercialized in 1922 [31]. The Dutch and German flax industries went through the same process at the same time [42]. The Concurrent variety (from Leenwandew, Holland) marketed from 1921, was the most popular variety grown in France until 1952 [42]. From 1944, Ireland produced two high quality series of flax plants with 
blue flowers, Liral and Stormont. Sowing techniques have changed, as machines have replaced manual sowing. This has also resulted in sowing by lines, typically 15 to $18 \mathrm{~cm}$ initially as wheat sowing machines were used (wheat seeds are larger than flax seeds). As dedicated sowing equipment for flax became available this distance reduced to 7 to $10 \mathrm{~cm}$ and the quantity of seeds was better controlled resulting in more regular stems [31]. The quality of seeds has improved significantly since 1939. Today seeds are certified, guaranteeing the identity and purity of the variety, the germination capacity (nearly always better than 96\%), and the sanitary quality [33].

Retting techniques: After uprooting the stems are retted, in order to facilitate the extraction of the fibres by the degradation of the cortical tissues surrounding the fibre bundles and of the pectic middle lamellae, thanks to the action of fungi and bacteria. The following techniques can be employed:

- Retting in standing water. The plants (in bundles) are immersed in tanks (in ditches in Ireland) of cold water for 6 to 15 days, depending on the water temperature. This process uses the bacterial attack of mid-cell walls to facilitate fibre bundle extraction after drying. It has not been used in Europe for about a century for environmental reasons.

- Retting in running water is identical, but takes place in a river or stream. This technique is now forbidden as it results in water pollution (dead fish, unpleasant smells...). It was stopped in Brittany (France) in 1909 [43] and in the Lys, the river running along the frontier between France and Belgium, in 1943 [31].

- Warm water retting was invented at the end of the $18^{\text {th }}$ century. Progress in chemical engineering led to research into alternative retting processes, less random, more productive and less harmful to the environment. This technique consists of soaking plants in water at $32^{\circ} \mathrm{C}$ for around 60 hours [43]. The technique was used in Ireland but, as for other water retting methods requires the waste water to be treated.

- Ground or dew retting gradually replaced all these water-based techniques and is still used today in Europe. This technology is justified for two main reasons; the lower cost (for ground retting it is natural micro-organisms which degrade the pectines followed by air drying) and the reduction in environmental impact. Wet retting requires large volumes of water, the need to dispose of extracted products, and an optimized low energy drying system. Enzyme retting may be a future option [44] , either for a complete treatment or after initial ground retting, but also has an associated cost [ 61].

Control of the degree of retting and the fibre properties is still manual today. The person responsible for the crop checks the ease of extraction of fibres manually and decides when to stop the retting. Wet retting 
was considered superior to ground retting, the retted stems are more homogeneous and the operator can control the immersion time more accurately. It has been shown that the mechanical properties of the flax fibres change during the retting process [46] [47].

Farm machinery: Uprooting plants at maturity was a time-consuming operation, requiring a considerable workforce (10 to 20 workers to harvest a hectare in a day if the flax was hand-sown, a bit faster if it was sown in lines). Up to 1940 flax was harvested manually [31][43]. The first harvesting machines appeared in 1935 but took time to be accepted. They provided improved efficiency but were expensive with respect to the usage time (a maximum of 15 to 20 days a year). Turning and collecting-and-tying machines appeared in 1950. The bundles of straw then had to be loaded onto lorries using pitchforks (between 1,200 and 1,500 bundles per hectare of flax). It is easy to understand that the absence of workers during and just after the Second World War resulted in a significant reduction in cultivated field areas. The extraction of fibre bundles from the stems is achieved by a scutching operation. The first scutching machines appeared around 1920 and were not very efficient. Mechanical scutching only started to replace the Flamand mills in the period from 1930-1939 thanks to Belgian machine makers. These first machines used the same principle as those employed today, belts to transport the straw, beaters and turbines [31].

\subsection{Fibre geometry, 1927-2020}

Flax plants (linum usitatissimun L.) have changed over time due to variety selection and changes in agricultural practices. This has resulted in an increase in fibre yield (see section 5.1). As a result, there is now a higher proportion of fibres in the stems and an increase in the height of the plants. This increase in height has been accompanied by improved resistance to lodging (during the growth of the flax, the plants may lie down on the ground, usually under the combined effect of wind and rain. This mechanical instability is called lodging). One would therefore expect that the elementary fibre length has also increased.

Table 4 provides information on the geometry of single fibres [48][49][50][51][52][31][53][54][55]. Several important points may be noted:

- A comparison between the values shows that the fibre dimensions measured are similar (no difference between old and current fibres). Moreover, L/D values are reproducible, with a high average value of $1349+/-364$, highlighting the reinforcement potential of flax fibres. The aspect ratio is critical for reinforcement in composite materials. Load transfer takes place between fibres and matrix so in order to benefit from the high fibre strength a high L/D value is essential.

- It is assumed that the data in Table 4 were measured on individual fibres. However, elementary fibres are very short and difficult to handle. Note that there is little information on the varieties, the 
growth conditions and the test protocols, in particular, the possible use of solvent to individualise the elementary fibres is rarely addressed.

- The fibre dimensions show scatter, which can be explained by their intrusive development, the plant growth conditions and the sampling zone [56]. Concerning the latter point the fibres taken from the upper or lower parts of the stem are shorter [55], for example a mean length of $16 \mathrm{~mm}$ at the bottom, $35.5 \mathrm{~mm}$ in the middle and $17.2 \mathrm{~mm}$ at the top.

\subsection{Mechanical properties of elementary fibres}

It is interesting to examine whether the tensile properties of flax fibres have changed since 1939. This section will address this question. The data available from that period are (among others):

- In 1936 Meyer and Lotmar [57] estimated the fibre stiffness by measuring the propagation speed of longitudinal waves, which avoided having to measure the fibre section. This was not a simple measurement, particularly with the equipment available at the time and on such small diameter samples. The modulus was estimated to be between $78.5 \mathrm{GPa}$ and $108 \mathrm{GPa}$.

- In 1937, De Bruyne [4] quotes values from Mark [58] indicating a flax fibre tensile strength between 360 and 1,100 MPa and a failure strain of $1.8 \%$.

These results show high modulus values compared to those measured over the last 20 years or so, which may be due to measurement uncertainties of the method used. On the other hand, the strength and failure strain values published by De Bruyne are in the same range as currently measured properties. Today a large database exists for values from elementary fibre tests. Comparisons of average mechanical properties gathered from 65 different batches (of 24 publications) were published by Baley et al. [59]. This represents over 4,000 fibre tests, on 17 varieties of flax (textile and oilseed) grown in Normandy (France) between 1993 and 2017. The average tangent modulus is $52.3 \pm 8.3 \mathrm{GPa}$, the average strength is $945 \pm 200 \mathrm{MPa}$ and $2.09 \pm 0.4 \%$ for the failure strain. The mean diameter of these fibres was $16.6 \pm 2.7$ $\mu \mathrm{m}$.

Care is needed in citing modulus values as flax fibres show non-linear tensile behaviour [60] and the values given above correspond to the tangent modulus in the second part of the stress-strain plot, as proposed in the standard NF T 25-501-2 [61]. Bensadoun et al. 2017 [62] studied the tensile behaviour of flax fibres (Aramis variety) and defined an initial modulus $\left(\mathrm{E}_{\mathrm{f} 1}\right)$ and a tangent modulus at the end of the test $\left(\mathrm{E}_{\mathrm{f} 2}\right)$. A significant difference was noted, Table 5, the initial stiffness $\mathrm{E}_{\mathrm{f} 1}$ is higher than the second value $\mathrm{E}_{\mathrm{f} 2}$. In that work the fibre stiffness was correlated with the stiffness of unidirectional plies. 
Using an inverse calculation, it is possible to estimate the mechanical properties of fibres from the longitudinal properties of a unidirectional ply if the fibre volume content is known (assuming that there are no voids). Simple micromechanics models for composite longitudinal tensile strength $\sigma_{\mathrm{cL}}$ can be developed from the rule of mixtures for longitudinal stress.

$$
\sigma c L=V f * \sigma f L+(1-V f) * \sigma m=V f * \sigma f L+(1-V f) * \sigma f L * E m / E f L
$$

Where $E_{\mathrm{fL}}$ is the longitudinal modulus of the fibre, $\mathrm{E}_{\mathrm{m}}$ is the modulus of the matrix and $\mathrm{V}_{\mathrm{f}}$ is the fibre volume fraction, $\sigma_{\mathrm{fL}}$ is the longitudinal strength of the fibre and $\sigma_{\mathrm{m}}$ the stress in the matrix at the failure strain. The main assumptions of this model are: Linear behavior of matrix and fibres, matrix failure strain is assumed to be greater the fibre failure strain, fibre tensile strength is constant, constant fibre diameter (the fibre strength is a function of the diameter), uniform fibre distribution, continuous fibres, no defects (the presence of defects will reduce the fibre strength), and perfectly aligned fibres.

The reality is different, which explains the use of an efficiency factor $(\mathrm{K}) . \mathrm{K}$ is a purely empirical fitting parameter with no underlying physical meaning:

$$
\sigma c L=K * V f * \sigma f L+(1-V f) \sigma m=K * V f * \sigma f L+(1-V f) * \sigma f L * E m / E f L
$$

For unidirectional biocomposite materials, this factor $\mathrm{K}$ takes into account the main specificities of flax fibres [38]: Discontinuous fibres, variable geometry (length and diameter) and mechanical properties, fibre cross-section not constant, tapered fiber ends, polygonal fibre sections, presence of kink band defects, and reinforcement of composites by elementary fibres, bundles (more or less divided) and possibly also by bundle assemblies. In a bundle, the fibres are connected by middle lamella; thus, a bundle is itself a natural unidirectional composite reinforced by short fibres.

If we apply this inverse calculation to the properties of the flax/phenolic composites produced in 1939 with a fibre volume fraction of $70 \%$ [2], the modulus of the fibres can be estimated to be $58.8 \mathrm{GPa}$, and for a fibre content of $75 \%$ it is $64.4 \mathrm{GPa}$ [15]. These are slightly higher values than the mean values measured on elementary fibres (52.5 GPa) [59] using the NFT 25-502 standard [61], but very close to the initial modulus measured by Bensadoun et al. [62] (57 GPa). These results suggest that there has not been a significant change in the tensile properties of flax fibres since 1939, in spite of the very extensive work to improve variety selection (Figure 3). However, fibre tensile properties are not among the variety selection criteria. The selection criteria are the yield per hectare, the precocity (time to flowering and maturity), resistance to disease and resistance to flattening (lodging). The adaptation of the variety to the growing season is also relevant. Flax is traditionally planted in the spring (most of the flax grown in Europe is from spring varieties). However, in recent years, winter flax varieties have also been developed. 
This is in order to reduce the risk of erosion, by covering the soil from the autumn, and to adapt the growth conditions to climate changes, while limiting the consequences for the plant of drought stress at the end of spring [63]. This comparison correlates closely with the results of Goudenhooft et al. [36]. In their work four varieties of flax selected from the 1940s to 2011 were cultivated and fibre properties were tested; the study demonstrated that flax fibres preserve their good mechanical performances in spite of the anatomical differences at the stem scale. We do not know the exact properties of the polymer matrix used by DeBruyne. However, if we neglect the matrix and consider that the strength of a unidirectional composite is directly proportional to the quantity and strength of the fibres then the tensile strength of the fibres would be between $763 \mathrm{MPa}$ and $951 \mathrm{MPa}$ (with $\mathrm{K}=0.58$ ), i.e. an average value of $857 \mathrm{MPa}$. The K value (0.58) we have chosen here was taken from the work of Coroller et al. [29] who determined the K-factor for a range of UD epoxy-flax composites with varying levels of individualisation of the reinforcements. We have chosen to use the average value of the different K-factors calculated in that work. Figure 3B shows, in addition to the experimental results, an estimation of the strength versus fibre volume fraction based on Equation 2 (with $\mathrm{K}=0.58, \sigma_{\mathrm{fL}}=857 \mathrm{MPa}, \mathrm{E}_{\mathrm{fl}}=58.8 \mathrm{GPa}, \mathrm{E}_{\mathrm{m}}=2.5 \mathrm{GPa}$ ).

\subsection{Developments in flax reinforcements}

The elementary fibres extracted from flax plants to be used as composite reinforcement show two specific features: they are discontinuous and assembled in bundles. Their length is significant $\left(\mathrm{L}_{\mathrm{f}}>20 \mathrm{~mm}\right)$, (Table 2) compared to other plant fibres. Moreover, mechanically speaking, flax fibres are anisotropic. This signifies that the longitudinal mechanical properties of flax fibres are far superior to their transverse properties. After retting and scutching, a tape is obtained, which can be used for spinning. The aim of spinning is to separate the fibres and to twist them, in order to obtain a yarn with good tensile strength. When such a yarn is loaded in tension, the load transfer occurs by friction between the fibres. The yarns can then be woven, to produce a composite reinforcement, but while very common for synthetic fibres this is not optimal for flax fibres which are more easily damaged during these operations as shown in $[64][65]$

In the composite, the load transfer will involve the matrix and fibre/matrix interfaces. Some published studies show a good impregnation of plant fibre yarns, even with thermoplastic polymers, but the latter is highly dependent on the yarn structure and especially on twisting. Twisted yarns result in a mesostructure which is very heterogeneous, and cause local disorientation of fibres, while voids also remain [66][67][68][69][70], as it is difficult to wet fibres in the centre of twisted yarns. More generally, the question of impregnation of a preform (a woven fabric for example) by a matrix is complex if one wishes 
to obtain an optimum composite without porosity. This topic is particularly important for the RTM (Resin Transfer Moulding) process. In general, the heterogeneous microstructure of fiber preforms is considered to be the main reason for the non-uniform resin flow [71]. Hence, two different sizes of pore are observed in the fabric microstructure, very tiny pores inside the yarn and relatively large open gaps between the yarns. As the pore sizes are different, the flow characteristics vary in each zone. The viscous flow is dominant at the open gaps between the yarns while capillary wicking is the main type of flow at the micropores.

In order to optimize their performance, it is necessary to imagine other forms of reinforcement, such as non-wovens, unidirectionals or mats..., while taking advantage of the specific features of plant fibres at a reasonable cost. To obtain unidirectional plies, DeBruyne's innovation was to produce a preimpregnated layer of non-twisted fibres [2]. In more recent developments this approach has also been adopted, but other forms of semi-product have been developed and the establishment of a structured flax reinforcement supply chain is one of the major changes since De Bruyne's early work. For example:

- fibres linked together using the pectins from the plant, Figure 4.A. This technology is described in [72],

- preimpregnated plies with a thermoset resin matrix. This technology is used today for automotive applications [72],

- calendered plies (Figure 4.B) between two 2 films of thermoplastic polymer [73],

- assemblies of yarns with a weft yarn (Figure 4.C). This preform has the disadvantage of producing local changes in fibre volume fraction at the points where the weft ply crosses the warp plies, and causes misalignments.

- flax fabric consisting of an assembly of unidirectional tapes (Figure 4.D). Adhesive bonding may provide a solution to obtain yarns which can be handled during weaving without twisting [74].

Other novel reinforcement developments include bi-axial and tri-axial braids [75], 3-D weaving [76], fibre mats using paper-making techniques [77], non-wovens [78], local reinforcing grids [79], and preform rods for 3D and 4D printing [80]. A recent overview of commercially available flax reinforcement forms can be found in [81]. Novel reinforcements have consequences for manufacturing, and the reader is referred to a recent paper [74] which provides an overview of the specific features of flax fibres with respect to forming and composite manufacturing. 


\section{Why choose flax for composite reinforcement today?}

\subsection{Criteria for choice of flax reinforcement in composites}

It is interesting to examine how opinions on the use of flax fibre as a composite reinforcement have changed. Initially, De Bruyne in 1937 [4] used a fabric (woven twisted yarns) of cotton as a reinforcement. In 1939 [2], in order to improve the mechanical properties, he replaced cotton by flax, based on the better specific properties of the latter, and optimized the reinforcement construction by manufacturing unidirectional prepregs (non-twisted). At the time there were few fibrous reinforcements available, and flax allowed structural aeronautical elements to be produced. The choice was solely based on the capacity of these fibres to reinforce the matrix polymers available. Subsequently the development of new manufacturing technology (for reinforcements and composites) resulted in new reinforcements. For example, the production of glass fibres began in 1937 [82] . After the Second World War, there was an increase in production for three main applications: electrical insulation, decorative fabrics, and composite materials. For these new materials, the 1950 s to 1970 s were a period of learning and developing new technologies associated with prototypes; industrialization and the marked industrial expansion of composite materials only really started in the 1980s. Today biocomposites are mainly used in the transport sector [83]. This is an industry which has experimented with environmentally friendly composites since Henry Ford in 1941, who tested car body panels made from a fibre-reinforced soyprotein plastic [84][85]. The Trabant is an example of the early use of natural-fibre-reinforced composites in automotive applications. Introduced in 1958 in the German Democratic Republic the roof, boot lid, bonnet, wings and doors were all manufactured from a thermosetting phenolic resin reinforced with cotton fibres [86]. To accept a material change on a part, the automotive industry today imposes various selection criteria such as: high specific mechanical properties (properties divided by density, in order to reduce $\mathrm{CO}_{2}$ emissions [87]), acceptable cost (either purchase or in-service) and efficient production rates (automation capacity of the manufacturing process) [88]. Other criteria include the environmental impact throughout the lifetime, damage resistance, repairability and end-of-life management. Biocomposites must respond to the same challenges as those facing composites reinforced with synthetic fibres. For example, in addition to the criteria noted above, there is a need for improved long term behaviour, better design and manufacturing methods, and optimization of constituents (particularly the matrix). Composite property monitoring, throughout the lifetime of the material, by integration of novel functions, is also an objective [99]. Today, the use of plant fibres is no longer simply a material substitution (natural fibres replacing glass fibres); they are specifically chosen because: they 
are from a renewable source, they are both durable and biodegradable, the specific mechanical performance of certain fibres is very good, they require considerably less energy than glass fibres to produce, and their incineration enables energy to be recovered. The following arguments are put forward to promote the transition to more environmentally friendly materials and to justify these choices:

i) Reduced environmental impacts and $\mathrm{CO}_{2}$ storage [73][93][100][90] through eco-design methods. However, using biobased constituents does not necessarily result in a reduction in environmental impact; a life cycle analysis must be performed.

ii) Weight gains, in certain cases these are possible [93][91], due to the lower fibre density compared to glass fibres.

iii) Different end-of-life scenarios: for example, recycling by mechanical fragmentation and remoulding if the matrix is a thermoplastic, energy recovery, and composting if the matrix allows it and if there are no toxic products in the formulation [91][92][93][94].

iv) The possibility to give a natural finish to moulded parts [73][95]. However, if the aim is only to give a green image to a product (green washing) then the argument is not durable.

v) Improved product image by the association with Nature [106][96].

vi) Reduced human health impacts for operators [103], particularly in the handling of composite reinforcements.

vii) Local fibre production, in some cases [99].

viii) Preparation of the introduction of new legislation with environmental constraints (e.g. Reach) [99].

ix) Providing strategic value to a product through the use of innovative materials [97][98].

\subsection{Environmental interest for using flax fibre as composite reinforcement}

Regarding crop cultivation, it appears that irrigation is the main contributor to energy consumption; this strongly penalizes the environmental assessment of the plant fibre production. Thus, the choice of the species, with regard to the available water in the cultivation area, is very important, some species requiring much less water than others. This is the case of flax, which only needs $150-250 \mathrm{~mm}$ of water during growing compared to 450 for kenaf and even 800-1,000 for cotton [9]; consequently, 7,000-29,000 liters of water are required [99] to produce $1 \mathrm{~kg}$ of cotton fibres and only 600-1000 liters for $1 \mathrm{~kg}$ of scutched flax fibres [35]. In temperate European areas, cultivation of flax does not require irrigation. During the cultivation phase, the impact of the use of fertilizers and pesticides is also important on the environmental balance 
sheet, as too much use of these products leads to a high eutrophication of water; plants with annual fibres such as flax have much lower consumption compared to other fibres. For example, cotton cultivation alone consumes almost a quarter of the pesticides sold worldwide [99]. Regardless of the plant under consideration, the nature of the soil and the climate must also be taken into account. In the case of flax, crops are grown in quality soils that require little nitrogen input; good soil can greatly improve the environmental impact of the crop. This has an impact on the fibre yield, which once again is clearly to flax's advantage, with productions of over 2 tons per hectare of scutched fibre, far above most other plant fibres and this has a major impact on the environmental impact of land use. This should be seen in conjunction with retting and extraction methods which also contribute to improving these impacts. When a large amount of water or mechanical energy is consumed, the environmental balance sheet is penalized, as is the case, for example, for water retting processes used for jute or the energy consuming technologies used to extract bamboo fibres [100]. To conclude, it appears that the production of scutched flax fibres remains very efficient from an environmental point of view, for $1 \mathrm{~kg}$ of fibre, the energy cost has been estimated at 4.4 MJ against $45 \mathrm{MJ}$ for glass fibres [35] and 33.1 MJ for $1 \mathrm{~kg}$ of cotton yarn [89]. This fully justifies their use as a reinforcement for more environmentally friendly composites.

\section{Conclusion}

Flax production has been maintained in Europe since 1939 in certain countries (France, Belgium and Holland), because there is still a demand for high quality fibres for the textile industry (the main market), and in particular for clothing; these fibres are known to be comfortable to wear.

The use of plant fibres to reinforce polymers is developing a new market, which is often described as a novel application. However, given that flax fibres were developed for aircraft parts in 1939, it is tempting to conclude that there is nothing new, but that is too simple. Of course, the composites industry has developed considerably over the last decades and the gradually increasing amount of composites in aircraft structures shows this quite clearly. The current novelty with respect to biocomposites is their increasing industrialization, rather than the materials themselves, and this is leading to more competition between materials. The results in this paper allow some conclusions to be drawn with respect to the changes in flax fibres over the last 80 years:

- The potential for reinforcement of polymers by flax fibres was demonstrated in 1939, and the mechanical properties of the composites produced at that time are close to those of current flax composites. An inverse method has been used to estimate the fibre properties. Such estimations are 
not simple as we do not have exact details of what was tested, but the published literature since 1927 indicates little change in fibre geometry (diameter and length).

- The varieties of flax grown (lin linum usitatissimun L.) have evolved with time to improve fibre yield, the mechanical resistance of the plants, their disease resistance, and to adapt to geograpical regions.

- Agricultural methods have changed significantly, with improved analysis of land and the development of new tools (for precision sowing, uprooting and turning).

- Retting methods have changed significantly, as water retting was banned in the 1960's, and only ground retting is now used in Europe,

- Fibre extraction techniques, while identical in principle have undergone automation and optimization.

Our knowledge of composite materials has also increased significantly as these materials have progressively integrated industrial production, but many of the basic principles for flax composite manufacture today were laid in that early work: The development of unidirectional fibre reinforcements without twist, of prepreg, and of processes to limit porosity and to account for anisotropy were already initiated 80 years ago. If this development is to continue it will be necessary to 'think biocomposites ', taking account of the particular properties of plant fibres (strong anisotropy, discontinuous reinforcements, fibre assemblies in the plant stem more or less separated by the extraction process). In addition, industrial applications require guarantees on the quality and quantity of fibres available each year at a competitive price. It is nevertheless possible to qualify these biocomposites as materials of the future, as they use renewable resources, produce low environmental impacts and provide end of life solutions well beyond the reasons for their initial development as structural materials 80 years ago.

\section{References}

[1] Kvavadze E, Bar-Yosef O, Belfer-Cohen A, Boaretto E, Jakeli N, Matskevich Z, et al. 30,000Year-Old Wild Flax Fibers. Science (80- ) 2009;325:1359. doi:10.1126/science.1175404.

[2] De Bruyne NA. Plastic progress. Some Further Developments in the manufacture and Use of Synthetic Materials for Aircraft Construction. Fligth 1939;12 january:77-9.

[3] Gordon J. Structures et Materiaux. L’explication mécanique des formes. Pour la science; 1994.

[4] de Bruyne NA. Plastic Materials for Aircraft Construction. J R Aeronaut Soc 1937;41:523-90. doi:10.1017/S0368393100107655.

[5] Bishopp J. Adhesives for Aerospace Structures. Handb. Adhes. Surf. Prep., William Andrew Publishing; 2011, p. 301-44. doi:10.1016/B978-1-4377-4461-3.10013-6.

[6] McMullen P. Fibre/resin composites for aircraft primary structures: a short history, 1 936--1984. Composites 1984;15:222-30. doi:10.1016/0010-4361(84)90279-9.

[7] Cotterell B. Fracture and life. Imperial College Press; 2010.

[8] Hill C, Hughes M. Natural Fibre Reinforced Composites. Opportunities and Challenges. J 
Biobased Mater Bioenergy 2010;4:148-58. doi:10.1166/jbmb.2010.1079.

[9] Bourmaud A, Beaugrand J, Shah DU, Placet V, Baley C. Towards the design of highperformance plant fibre composites. Prog Mater Sci 2018;97:347-408.

doi:10.1016/j.pmatsci.2018.05.005.

[10] Eder M, Arnould O, Dunlop JWC, Hornatowska J, Salmén L. Experimental micromechanical characterisation of wood cell walls. Wood Sci Technol 2013;47:163-82. doi:10.1007/s00226012-0515-6.

[11] Middleton DH. Composite Developments in Aircraft Structures - Part 1. Aircr Eng Aerosp Technol 1992;64:2-8. doi:10.1108/eb037234.

[12] Hamerton I, Mooring L. The use of thermosets in aerospace applications. Woodhead Publishing; 2012. doi:10.1533/9780857097637.2.189.

[13] Bishopp J. Aerospace: A pioneer in structural adhesive bonding. In: Cognard PBT-H of A and S, editor. Adhes. Sealants, vol. 1, Elsevier Science Ltd; 2005, p. 215-347. doi:10.1016/S18745695(02)80006-9.

[14] Bishopp JA. The history of Redux ${ }^{\circledR}$ and the Redux bonding process. Int J Adhes Adhes 1997;17:287-301. doi:https://doi.org/10.1016/S0143-7496(97)00023-7.

[15] Smith S. A survey of plastics from the viewpoint of the mechanical engineer. Inst Mech Eng 1945:29-43. doi:10.1243/pime_proc_1945_152_012_02.

[16] Bos H, Molenveld K, Teunissen W, Van Wingerde A, Van Delft D. Compressive behaviour of unidirectional flax fibre reinforced composites. J Mater Sci 2004;39:2159-68. doi:10.1023/B:JMSC.0000017779.08041.49.

[17] Liang S, Gning PB, Guillaumat L. Quasi-static behaviour and damage assessment of flax/epoxy composites. Mater Des 2015;67:344-53. doi:10.1016/j.matdes.2014.11.048.

[18] Van Vuure AW, Baets J, Wouters K, Hendrickx K. Compressive properties of natural fibre composites. Mater Lett 2015;149:138-40. doi:10.1016/j.matlet.2015.01.158.

[19] Mahboob Z, El Sawi I, Zdero R, Fawaz Z, Bougherara H. Tensile and compressive damaged response in Flax fibre reinforced epoxy composites. Compos Part A Appl Sci Manuf 2017;92:118-33. doi:10.1016/j.compositesa.2016.11.007.

[20] Baley C, Lan M, Bourmaud A, Duigou A Le, Le Duigou A. Compressive and tensile behaviour of unidirectional composites reinforced by natural fibres: Influence of fibres (flax and jute), matrix and fibre volume fraction. Mater Today Commun 2018;16:300-6.

doi:10.1016/j.mtcomm.2018.07.003.

[21] Baley C, Kervoëlen A, Le Duigou A, Goudenhooft C, Bourmaud A. Is the low shear modulus of flax fibres an advantage for polymer reinforcement? Mater Lett 2016;185:534-6. doi:10.1016/j.matlet.2016.09.067.

[22] Gning PB, Liang S, Guillaumat L, Pui WJ. Influence of process and test parameters on the mechanical properties of flax/epoxy composites using response surface methodology. J Mater Sci 2011;46:6801-11. doi:10.1007/s10853-011-5639-9.

[23] Saadati Y, Lebrun G, Chatelain J-F, Beauchamp Y. Experimental investigation of failure mechanisms and evaluation of physical/mechanical properties of unidirectional flax-epoxy composites. J Compos Mater 2020;54:2781-801. doi:10.1177/0021998320902243. 
[24] Le Gall M, Davies P, Martin N, Baley C. Recommended flax fibre density values for composite property predictions. Ind Crops Prod 2018;114:52-8. doi:10.1016/j.indcrop.2018.01.065.

[25] Matthews FL. 5 - Compression. In: Hodgkinson JMBT-MT of AFC, editor. Woodhead Publ. Ser. Compos. Sci. Eng., Woodhead Publishing; 2000, p. 75-99.

doi:https://doi.org/10.1533/9781855738911.75.

[26] Buragohain M. Composite Structures: Design, Mechanics, Analysis, Manufacturing, and Testing. CRC Press; 2017.

[27] Baley C, Le Duigou A, Bourmaud A, Davies P. Influence of drying on the mechanical behaviour of flax fibres and their unidirectional composites. Compos Part A Appl Sci Manuf 2012;43:122633. doi:10.1016/j.compositesa.2012.03.005.

[28] Siniscalco D, Arnould O, Bourmaud A, Le Duigou A, Baley C. Monitoring temperature effects on flax cell-wall mechanical properties within a composite material using AFM. Polym Test 2018;69. doi:10.1016/j.polymertesting.2018.05.009.

[29] Coroller G, Lefeuvre A, Le Duigou A, Bourmaud A, Ausias G, Gaudry T, et al. Effect of flax fibres individualisation on tensile failure of flax/epoxy unidirectional composite. Compos Part A Appl Sci Manuf 2013;51:62-70. doi:10.1016/j.compositesa.2013.03.018.

[30] Bourmaud A, Le Duigou A, Gourier C, Baley C. Influence of processing temperature on mechanical performance of unidirectional polyamide 11-flax fibre composites. Ind Crops Prod 2016;84:151-65. doi:10.1016/j.indcrop.2016.02.007.

[31] Billaux P. Le lin au service des hommes: sa vie, ses techniques, son histoire. Baillère. Ed. Baillère; 1969.

[32] Renouard A. Études sur le travail des lins (culture, rouissage, teillage, peignage et filature). Vol.1. E. Lacroix, Paris; 1875.

[33] Bert F. Lin fibre - Culture et transformation. Arvalis; 2013.

[34] FRD, Ademe. Evaluation de la disponibilité et de l'accessibilité de fibres végétales à usage matériaux en France. Ademe; 2011.

[35] Le Duigou A, Davies P, Baley C. Environmental impact analysis of the production of flax fibres to be used as composite material reinforcement. J Biobased Mater Bioenergy 2011;5:153-65. doi:10.1166/jbmb.2011.1116.

[36] Goudenhooft C, Bourmaud A, Baley C. Varietal selection of flax over time: Evolution of plant architecture related to influence on the mechanical properties of fibers. Ind Crops Prod 2017;97:56-64. doi:10.1016/j.indcrop.2016.11.062.

[37] Arvalis. Arvalis-Info (https://www.arvalis-infos.fr) 2020.

[38] Jankauskienė Z, Gruzdevienė E. Recent results of flax breeding in Lithuania. Ind Crops Prod 2015;75:185-94. doi:https://doi.org/10.1016/j.indcrop.2015.07.024.

[39] Spielmeyer W, Lagudah ES, Mendham N, Green AG. Inheritance of resistance to flax wilt (Fusarium oxysporum f.sp. lini Schlecht) in a doubled haploid population of Linum usitatissimum L. Euphytica 1998;101:287-91. doi:10.1023/A:1018353011562.

[40] Gibaud M, Bourmaud A, Baley C. Understanding the lodging stability of green flax stems; The importance of morphology and fibre stiffness. Biosyst Eng 2015;137:9-21. doi:10.1016/j.biosystemseng.2015.06.005. 
[41] Bourmaud A, Gibaud M, Baley C. Impact of the seeding rate on flax stem stability and the mechanical properties of elementary fibres. Ind Crops Prod 2016;80:17-25.

doi:10.1016/j.indcrop.2015.10.053.

[42] Doré C, Varoquaux F. Histoire et amélioration de cinquante plantes cultivées. INRA, Paris; 2006.

[43] Montaigne J. Images du lin textile, -8000 ans +2000 ans. Rouen, France: ASI Com.; 1997.

[44] De Prez J, Van Vuure A, Ivens J, Aerts G, Van de Voorde I. Enzymatic treatment of flax for use in composites. Biotechnol Reports 2018;20:e00294. doi:10.1016/j.btre.2018.e00294.

[45] Akin DE, Foulk JA, Dodd RB, McAlister DD. Enzyme-retting of flax and characterization of processed fibers. J Biotechnol 2001;89:193-203. doi:10.1016/S0168-1656(01)00298-X.

[46] Martin N, Mouret N, Davies P, Baley C. Influence of the degree of retting of flax fibers on the tensile properties of single fibers and short fiber/polypropylene composites. Ind Crops Prod 2013;49:755-67. doi:10.1016/j.indcrop.2013.06.012.

[47] Bourmaud A, Siniscalco D, Foucat L, Goudenhooft C, Falourd X, Pontoire B, et al. Evolution of flax cell wall ultrastructure and mechanical properties during the retting step. Carbohydr Polym 2019;206:48-56. doi:10.1016/j.carbpol.2018.10.065.

[48] Von Wiesner J. Die Rohstoffe des “flanzenreiches. 4th edn. 2 volumes. W. Engelmann, Leipzig,; 1927.

[49] Matthews JM. The textile fibers (4th edn),. John Wiley and Sons, New York; 1931.

[50] Plonka F. Les variétés de lin et leurs principales maladies cryptogamiques. INRA, Paris; 1956.

[51] Koch PA. Microscopie and chemical testing of textiles. Chapman and Hall, london; 1963.

[52] Kirby RH. Vegetable fibres: Botany, Cultivation, and Utlization. Leonard Hill Ldt; 1963.

[53] Catling D, Grayson J. Identification of Vegetable Fibres. Chapman and Hall; 1982. doi:978-94011-8070-2.

[54] Gorshkova T, Ageeva M, Salnikov V, Pavlencheva N, Snegireva A, Chernova, T Chemikosova S. стадии формирования лубяных волокон Linum usitatissimum (Linaceae) (Stages of bast fibres formation in Linum usitatissimum (Linaceae)). Bot J 2003;88:1-11.

[55] Baley C, Goudenhooft C, Gibaud M, Bourmaud A. Flax stems: from a specific architecture to an instructive model for bioinspired composite structures. Bioinspiration and Biomimetics 2018;13:12. doi:10.1088/1748-3190/aaa6b7.

[56] Goudenhooft C, Bourmaud A, Baley C. Flax (Linum usitatissimum L.) Fibers for Composite Reinforcement: Exploring the Link Between Plant Growth, Cell Walls Development, and Fiber Properties. Front Plant Sci 2019;10:23. doi:10.3389/fpls.2019.00411.

[57] Meyer KH, Lotmar W. Sur l'élasticité de la cellulose. (Sur la constitution de la partie cristallisée de la cellulose IV). Helv Chim Acta 1936;19:68-86. doi:10.1002/hlca.19360190110.

[58] Mark H. Physik und Chemie der Cellulose. Verlag von Julius Springer; 1932.

[59] Baley C, Gomina M, Breard J, Bourmaud A, Davies P. Variability of mechanical properties of flax fibres for composite reinforcement. A review. Ind Crops Prod 2019:111984. doi:https://doi.org/10.1016/j.indcrop.2019.111984.

[60] Baley C. Analysis of the flax fibres tensile behaviour and analysis of the tensile stiffness increase. Compos - Part A Appl Sci Manuf 2002;33:939-48. doi:10.1016/S1359-835X(02)00040-4.

[61] AFNOR NF T 25-501-2. Reinforcement fibres- Flax fibres for plastics composites. Part 2. 
Determination of tensile properties of elementary flax fibres (in French). AFNOR Edition; 2015.

[62] Bensadoun F, Verpoest I, Baets J, Müssig J, Graupner N, Davies P, et al. Impregnated Fibre Bundle Test for Natural Fibres used in Composites. J Reinf Plast Compos 2017;36:942-57. doi:10.1177/0731684417695461.

[63] Ezquer I, Salameh I, Colombo L, Kalaitzis P. Plant Cell Walls Tackling Climate Change: Biotechnological Strategies to Improve Crop Adaptations and Photosynthesis in Response to Global Warming. Plants 2020;9. doi:10.3390/plants9020212.

[64] Aslan M, Chinga-Carrasco G, Sørensen BF, Madsen B. Strength variability of single flax fibres. J Mater Sci 2011;46:6344-54. doi:10.1007/s10853-011-5581-X.

[65] Aslan M, Mehmood S, Madsen B, Goutianos S. The effect of processing on defects and tensile strength of single flax fibres. ECCM-14, 2010.

[66] Shah DU, Schubel PJ, Licence P, Clifford MJ. Determining the minimum, critical and maximum fibre content for twisted yarn reinforced plant fibre composites. Compos Sci Technol 2012;72:1909-17. doi:10.1016/j.compscitech.2012.08.005.

[67] Baets J, Plastria D, Ivens I, Verpoest I. Determination of the optimal flax fibre preparation for use in unidirectional flax-epoxy composites. J Reinf Plast Compos 2014;33:493-505. doi: $10.1177 / 0731684413518620$.

[68] Madsen B, Thygesen A, Lilholt H. Plant fibre composites - porosity and volumetric interaction. Compos Sci Technol 2007;67:1584-600. doi:10.1016/J.COMPSCITECH.2006.07.009.

[69] Berges M, Léger R, Placet V, Person V, Corn S, Gabrion X, et al. Influence of moisture uptake on the static, cyclic and dynamic behaviour of unidirectional flax fibre-reinforced epoxy laminates. Compos Part A Appl Sci Manuf 2016;88:165-77. doi:10.1016/j.compositesa.2016.05.029.

[70] Acera Fernández J, Le Moigne N, Caro-Bretelle AS, El Hage R, Le Duc A, Lozachmeur M, et al. Role of flax cell wall components on the microstructure and transverse mechanical behaviour of flax fabrics reinforced epoxy biocomposites. Ind Crops Prod 2016;85:93-108. doi:10.1016/j.indcrop.2016.02.047.

[71] Gueroult S, Lebel-Lavacry A, Park CH, Bizet L, Saouab A, Bréard J. Analytical modeling and in situ measurement of void formation in liquid composite molding processes. Adv Compos Mater 2014;23:31-42. doi:10.1080/09243046.2013.862383.

[72] Khalfallah M, Abbès B, Abbès F, Guo YQ, Marcel V, Duval A, et al. Innovative flax tapes reinforced Acrodur biocomposites: A new alternative for automotive applications. Mater Des 2014;64:116-26. doi:10.1016/j.matdes.2014.07.029.

[73] Baley C, Kervoëlen A, Lan M, Cartié D, Le Duigou A, Bourmaud A, et al. Flax/PP manufacture by automated fibre placement (AFP). Mater Des 2016;94:207-13. doi:10.1016/j.matdes.2016.01.011.

[74] Baley C, Gomina M, Breard J, Bourmaud A, Drapier S, Ferreira M, et al. Specific features of flax fibres used to manufacture composite materials. Int J Mater Form 2019;12:1023-52. doi:10.1007/s12289-018-1455-y.

[75] Jacquot P-B, Wang P, Soulat D, Legrand X. Analysis of the preforming behaviour of the braided and woven flax/polyamide fabrics. J Ind Text 2016;46:698-718. doi:10.1177/1528083715591592. 
[76] Lansiaux H, Soulat D, Boussu F, Labanieh AR. Development and Multiscale Characterization of 3D Warp Interlock Flax Fabrics with Different Woven Architectures for Composite Applications. FIBERS 2020;8. doi:10.3390/fib8020015.

[77] Roussière F, Baley C, Godard G, Burr D. Compressive and Tensile Behaviours of PLLA Matrix Composites Reinforced with Randomly Dispersed Flax Fibres. Appl Compos Mater 2012;19:171-88. doi:10.1007/s10443-011-9189-8.

[78] Das D. Introduction to composite nonwovens. In: Das D, Pourdeyhimi B, editors. Compos. nonwoven Mater. Struct. Prop. Appl., Cambridge, UK: Woodhead Publishing Series in Textiles: Number 155; 2014.

[79] Verpoest I, Baley C. Flax and hemp fibre composites, a market reality. The biobased solutions for the industry. JEC Group; 2108.

[80] Le Duigou A, Correa D, Ueda M, Matsuzaki R, Castro M. A review of 3D and 4D printing of natural fibre biocomposites. Mater Des 2020;194:108911.

doi:https://doi.org/10.1016/j.matdes.2020.108911.

[81] Hendrickx K. Biosourcing:What Are the Available Reinforcements on the Market? Flax Hemp Fiber Compos. a Mark. Real., JEC Group; 2018, p. 33-44.

[82] De Banville E, Verilhac J. La lente émergence de «matériaux nouveaux », les composites. Rev d'économie Ind 1985:132-45.

[83] Adekomaya O. Adaption of green composite in automotive part replacements: discussions on material modification and future patronage. Environ Sci Pollut Res 2020;27:8807-13. doi:10.1007/s11356-019-07557-x.

[84] Hänninen T, Hughes M, Baur E, Otremba F, Huber T, Graupner N, et al. Composites. Ind. Appl. Nat. Fibres, John Wiley \& Sons, Ltd; 2010, p. 381-480. doi:10.1002/9780470660324.ch19.

[85] Shurtleff W, Aoyagi A. Henry Ford ans his researchers - History of their work with soybeans, soyfoods and chemurgy (1928-2011): extensively annotated bibliography and sourcebook. Soyinfo Center; 2011.

[86] Sonntag W, Barthel W. Kunststoff für Karosserieverkleidungen. Proc. 4th Int. Nat. Fibre Compos. Symp. Kassel, Ger., Institut f ur Werkstofftechnik, Universit”at Gh Kassel, Kunststoffund Recyclingtechnik; 2002, p. 1-1-1-27.

[87] Taub A, De Moor E, Luo A, Matlock DK, Speer JG, Vaidya U. Materials for Automotive Lightweighting. In: Clarke D, editor. Annu. Rev. Mater. Res., vol. 49, 2019, p. 327-59. doi:10.1146/annurev-matsci-070218-010134.

[88] Rajak DK, Pagar DD, Kumar R, Pruncu CI. Recent progress of reinforcement materials: a comprehensive overview of composite materials. J Mater Res Technol 2019;8:6354-74. doi:https://doi.org/10.1016/j.jmrt.2019.09.068.

[89] Joshi S., Drzal L., Mohanty A., Arora S. Are natural fiber composites environmentally superior to glass fiber reinforced composites? Compos Part A Appl Sci Manuf 2004;35:371-6. doi:10.1016/J.COMPOSITESA.2003.09.016.

[90] Pervaiz M, Sain MM. Carbon storage potential in natural fiber composites. Resour Conserv Recycl 2003;39:325-40. doi:10.1016/S0921-3449(02)00173-8.

[91] Witayakran S, Smitthipong W, Wangpradid R, Chollakup R, Clouston PL. Natural Fiber 
Composites: Review of Recent Automotive Trends. In: Hashmi S, Choudhury IA, editors. Encycl. Renew. Sustain. Mater., Oxford: Elsevier; 2017, p. 166-74. doi:10.1016/B978-0-12-8035818.04180-1.

[92] Bourmaud A, Baley C. Investigations on the recycling of hemp and sisal fibre reinforced polypropylene composites. Polym Degrad Stab 2007;92:1034-45. doi:10.1016/j.polymdegradstab.2007.02.018.

[93] Kumar S, Hiremath S. Natural Fiber Reinforced Composites in the Context of Biodegradability: A Review. In: Hashmi S, Choudhury IA, editors. Encycl. Renew. Sustain. Mater., Oxford: Elsevier; 2020, p. 160-78. doi:10.1016/B978-0-12-803581-8.11418-3.

[94] Shanks R. Recycled synthetic polymer fibers in composites. In: Baillie C, Jayasinghe R, editors. Green Compos. (Second Ed. Second Edi, Woodhead Publishing; 2017, p. 73-93. doi:10.1016/B978-0-08-100783-9.00024-1.

[95] Pil L, Bensadoun F, Pariset J, Verpoest I. Why are designers fascinated by flax and hemp fibre composites? Compos Part A Appl Sci Manuf 2015;83:193-205. doi:10.1016/j.compositesa.2015.11.004.

[96] Baley C. Fibres naturelles de renfort pour matériaux composites. Tech l'ingénieur Matériaux Compos Présentation Renforts 2020;base docum:35 pages.

[97] Rose C. Designing for composites: Traditional and future views. In: Baillie C, Jayasinghe R, editors. Green Compos. (Second Ed. Second Edi, Woodhead Publishing; 2017, p. 7-18. doi:10.1016/B978-0-08-100783-9.00002-2.

[98] Baillie C, Jayasinghe R. Green composites: Towards a sustainable future? In: Baillie C, Jayasinghe R, editors. Green Compos. (Second Ed. Second Edi, Woodhead Publishing; 2017, p. 1-5. doi:10.1016/B978-0-08-100783-9.00001-0.

[99] WWF. The impact of cotton on fresh water resources and ecosystems. A preliminary synthesis. 1999.

[100] van der Werf HMG, Turunen L. The environmental impacts of the production of hemp and flax textile yarn. Ind Crops Prod 2008;27:1-10. doi:10.1016/j.indcrop.2007.05.003. 


\section{Figure captions}

Figure 1: Gordon Aerolite Blenheim spar design based on the metacarpal bone of the vulture [13].

Figure 2: Construction of the Spitfire fuselage using Gordon Aerolite [13].

Figure 3: (A) Longitudinal tensile modulus (E1) of unidirectional composites versus fibre volume fraction, (B) Strength versus fiber volume fraction for unidirectional flax/thermoset composites.

$[4][2][15][16][17][18][19][20][21][22][23]$.

Figure 4: (A) Unidirectional reinforcement with fibres linked by pectins (scale bar in $\mathrm{cm}$ ).

(B) Unidirectional fibres between two thermoplastic polymer films (width $=15 \mathrm{~mm}$, thickness $=0.3 \mathrm{~mm}$ )

(C) Unidirectional warp fibres linked by weft yarn (scale bar in $\mathrm{cm}$ ).

(D) Flax fabric consisting of an assembly of unidirectional tapes (scale bar in $\mathrm{cm}$ ).

\section{Tables}

Table 1. Unidirectional composites reinforced by cotton trichomes or flax fibres. Longitudinal compressive and tensile properties $[4][2][15][16][17][18][19][20][21][22][23]$. (*) Chemical treatments $=$ Flax dewaxed (ethanol extraction $)+$ melamine formaldehyde $(\mathrm{MF})$. This resin penetrates the cell wall of flax fibres (Concentration MF in solution 20\%).

Table 2. Fibre production per hectare [32][31][33][34].

Table 3. Distribution of the different co-products after scutching of flax stems [33][34][35].

Table 4. Aspect ratio of elementary flax fibres (data from the literature between 1927 and 2018). $[48][49][50][51][52][31][53][54][55]$.

Table 5. Longitudinal tensile properties on elementary flax fibres (Aramis variety) [62]. Two tangent modules were determined. $\mathrm{E}_{\mathrm{fL} 1}$ is the maximal tangent modulus for low strain. $\mathrm{E}_{\mathrm{fL} 2}$ is the tangent modulus for the second part of the curve (strain $>0.5 \%$ ) according to the standard NF T25-502 [61]. 
Figure 1: Gordon Aerolite Blenheim spar design based on the metacarpal bone of the vulture [13].
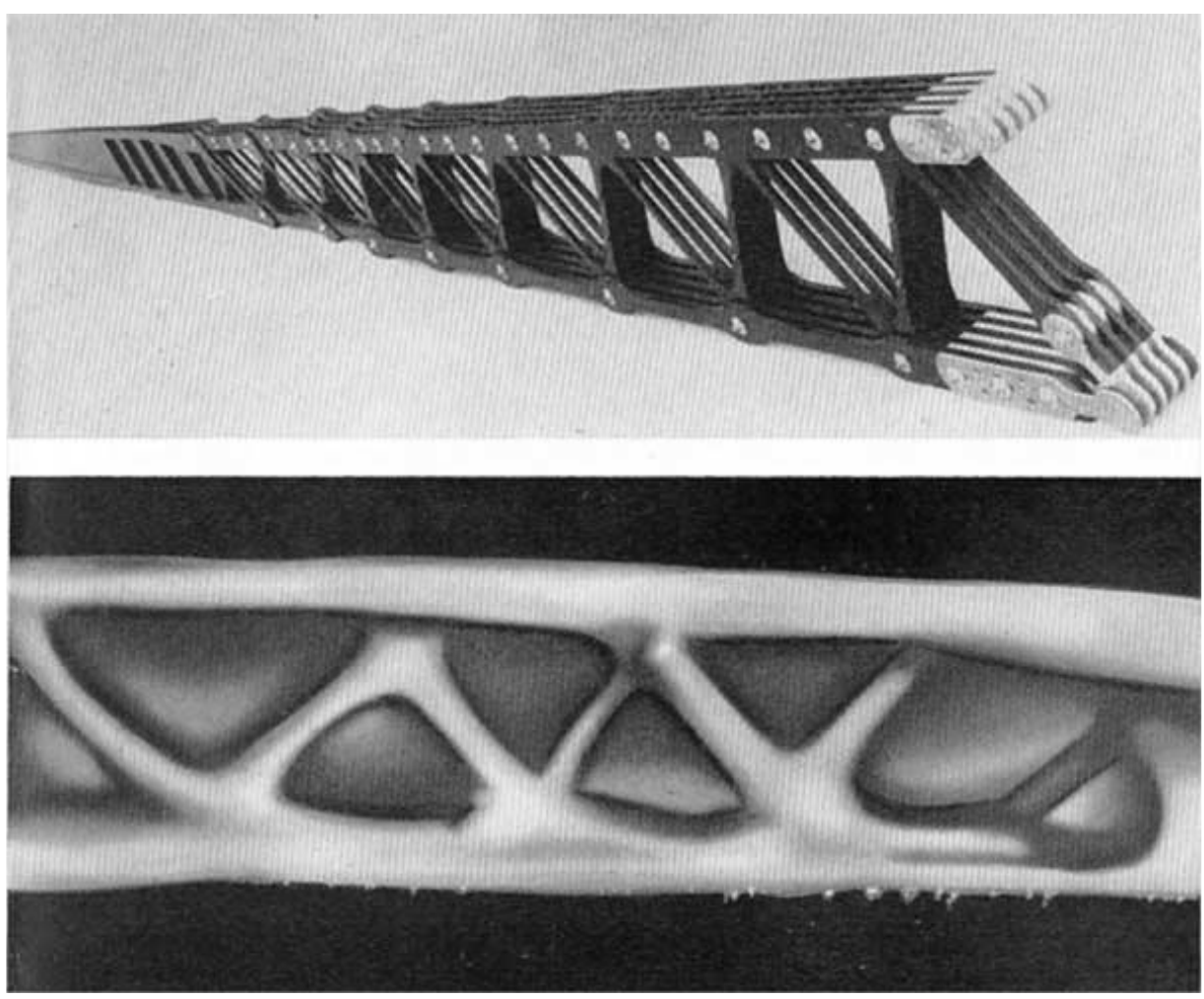

Figure 2: Construction of the Spitfire fuselage using Gordon Aerolite [13].

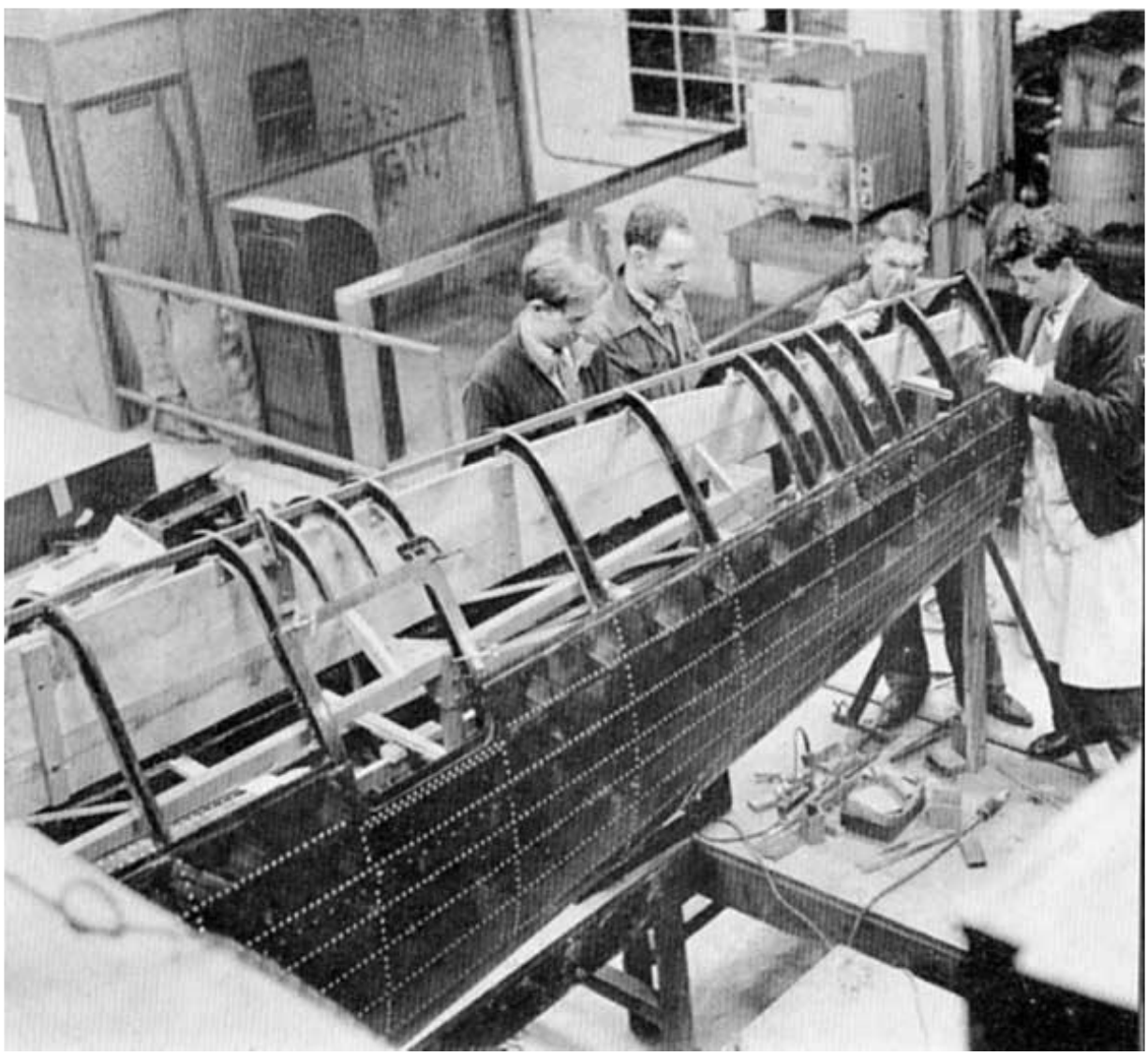


Figure 3: (A) Longitudinal tensile modulus (E1) of unidirectional composites versus fibre volume fraction, (B) Strength versus fiber volume fraction for unidirectional flax/polymer composites [4][2][15][16][17][18][19][20][21][22][23].

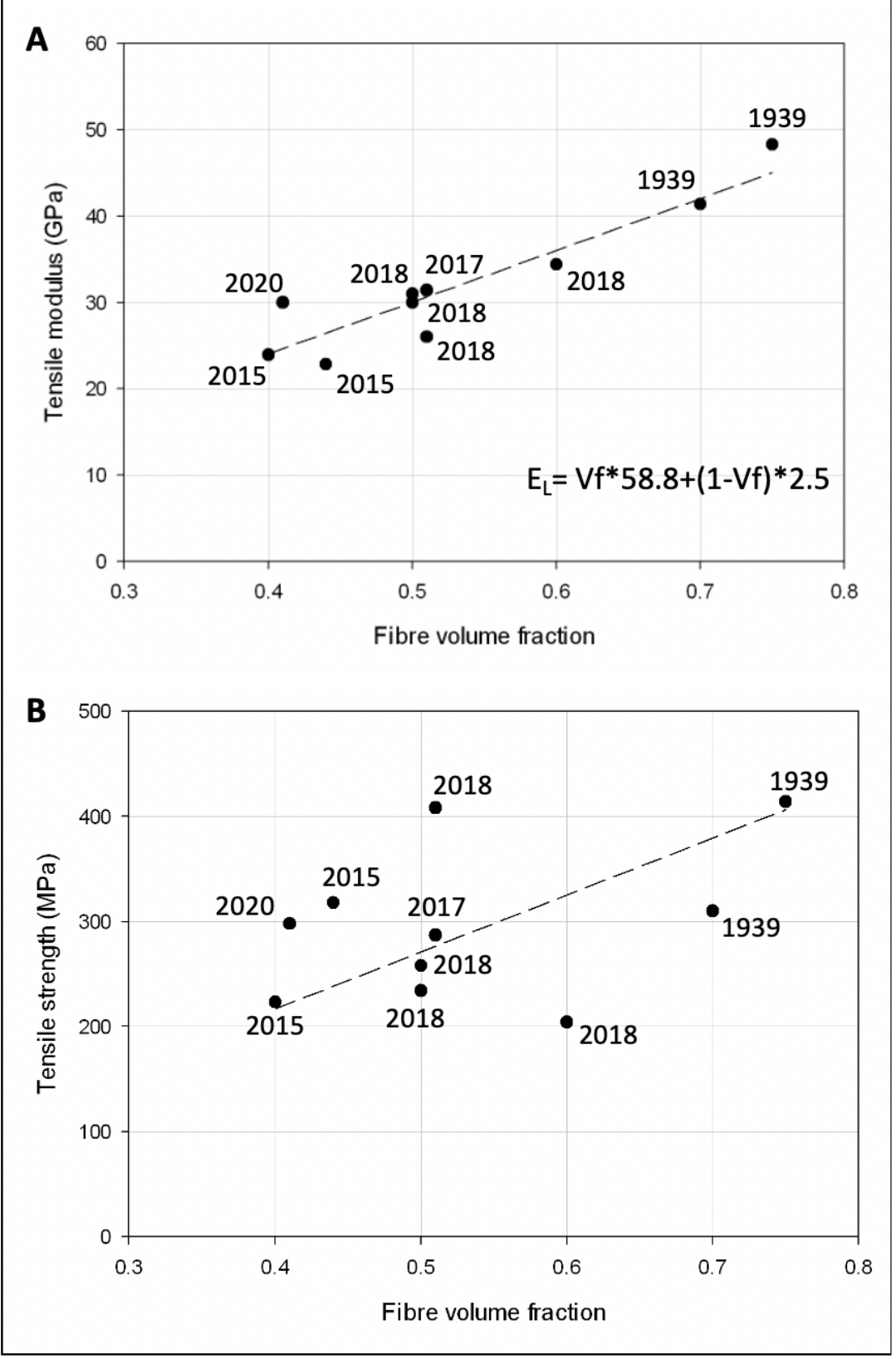


Figure 4: (A) Unidirectional reinforcement with fibres linked by pectins (scale bar in $\mathrm{cm}$ ). (B) Unidirectional fibres between two thermoplastic polymer films (width $=15 \mathrm{~mm}$, thickness $=0.3$ $\mathrm{mm}$ ). (C) Unidirectional warp fibres linked by weft yarn (scale bar in $\mathrm{cm}$ ). (D) Flax fabric consisting of an assembly of unidirectional tapes (scale bar in $\mathrm{cm}$ )

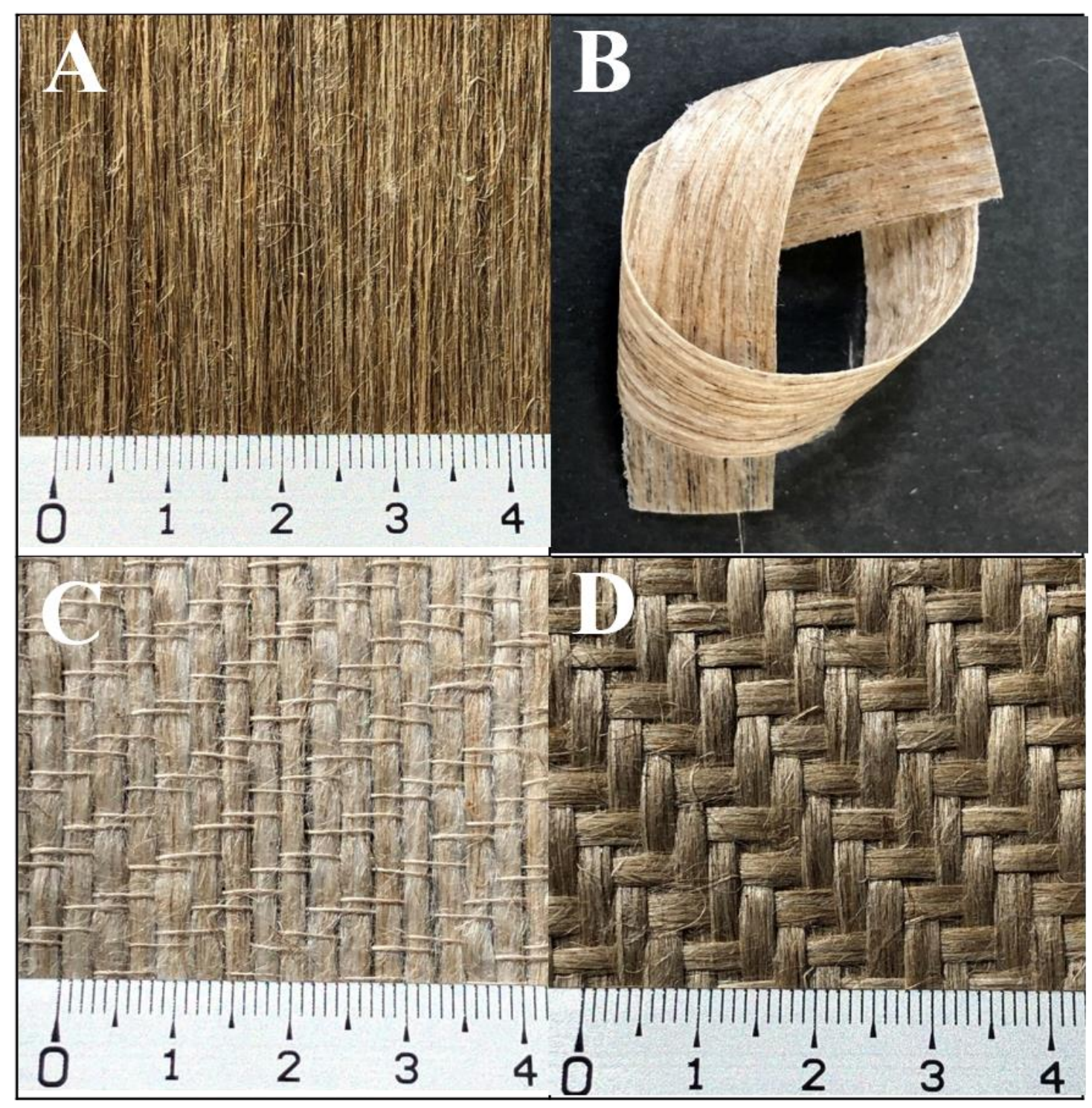


Table 1: Unidirectional composites reinforced by cotton trichomes or flax fibres. Longitudinal compressive and tensile properties [4][2][15][16][17][18][19][20][21][22][23].

(*) Chemical treatments = Flax dewaxed (ethanol extraction) + melamine formaldehyde (MF). This resin penetrates the cell wall of flax fibres (Concentration MF in solution $20 \%)$

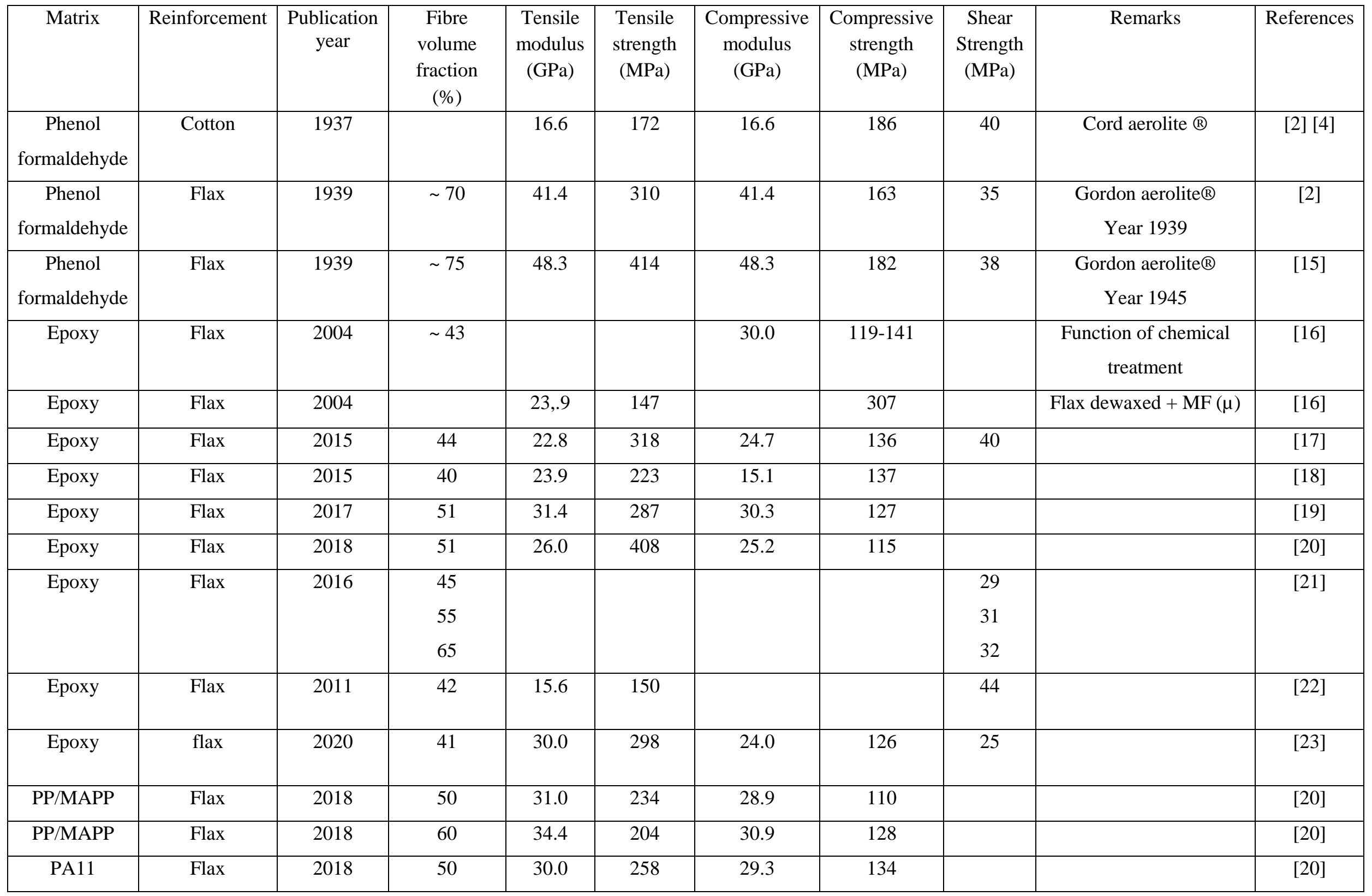


Table 2: Fibre production per hectare.

\begin{tabular}{|l|c|c|c|}
\hline Period & $\begin{array}{c}\text { Fibres Yield, } \\
\mathrm{kg} / \text { Hectare }\end{array}$ & Location & Comment \\
\hline 1871 & 1,175 & Gand (Belgium) & Experimental plots [32] \\
\hline $1918-1939$ & 127 & England & {$[31]$} \\
\hline 2018 & 510 & Ireland & {$[33]$} \\
\hline Objective 2020 & 2,300 & France & {$[34]$} \\
\hline
\end{tabular}

Table 3: Distribution of the different co-products after scutching of flax stems

\begin{tabular}{|c|c|c|c|c|c|}
\hline \multicolumn{2}{|c|}{ Fibres } & & & & \\
\hline Scutched flax (\%) & Flax tow $(\%)$ & Wood $(\%)$ & Seeds $(\%)$ & Dust (\%) & References \\
\hline 22 & 15 & 50 & 5 & 8 & {$[33]$} \\
\hline $15-25$ & $10-15$ & $45-50$ & $5-8$ & 10 & {$[34]$} \\
\hline 23.5 & 13.5 & 48.5 & 5.5 & 10 & {$[35]$} \\
\hline
\end{tabular}


Table 4: Aspect ratio of elementary flax fibres (data from the literature between 1927 and 2018) (Lf: fibre length, Df: diameter) [48][49][50][51][52][31][53][54][55].

\begin{tabular}{|l|l|l|l|c|}
\hline Publication year & $\mathrm{L}_{\mathrm{f}}(\mathrm{mm})$ & $\mathrm{D}_{\mathrm{f}}(\mu \mathrm{m})$ & $\mathrm{L}_{\mathrm{f}} / \mathrm{D}_{\mathrm{f}}$ mean & References \\
\hline 1927 & $20-50($ mean 35) & $12-26($ mean 19) & 1,842 & {$[48]$} \\
\hline 1931 & $11-38($ mean 24.5$)$ & $12-25($ mean 18.5$)$ & 1,324 & {$[49]$} \\
\hline 1956 & $10-40$ & $15-25$ & 1,250 & {$[50]$} \\
\hline 1963 & $20-39($ mean 29.5$)$ & $11-31($ mean 21$)$ & 1,404 & {$[51]$} \\
\hline 1963 & 27 & 23 & 1,174 & {$[52]$} \\
\hline 1969 & $2-90$ & $12-18$ & 1,467 & {$[31]$} \\
\hline 1982 & $1.6-24($ mean 7.9$)$ & $11.68-31.96($ mean 19$)$ & 416 & {$[53]$} \\
\hline 2003 & $13-65($ mean 28.8) & $12-30($ mean 21) & 1,190 & {$[54]$} \\
\hline 2018 & $11-87($ mean 35.5) & Mean 17.1 & 2,076 & {$[55]$} \\
\hline
\end{tabular}

Table 5: Longitudinal tensile properties on elementary flax fibres (Aramis variety) [62]. Two tangent modules were determined. $\mathrm{E}_{\mathrm{fL} 1}$ is the maximal tangent modulus for low strain. $\mathrm{E}_{\mathrm{fL} 2}$ is the tangent modulus for the second part of the curve (strain $>0.5 \%$ ) according to the standard NF T25-502 [61].

\begin{tabular}{|l|l|c|c|c|c|}
\hline & \multicolumn{2}{|c|}{ Stiffness } & \multicolumn{2}{c|}{ Strength } & Strain at break, \% \\
\hline & Diameter $(\mu \mathrm{m})$ & $\mathrm{E}_{\mathrm{fL} 1}(\mathrm{GPa})$ & $\mathrm{E}_{\mathrm{fL} 2}(\mathrm{GPa})$ & $\sigma_{\mathrm{fLu}}(\mathrm{MPa})$ & $\varepsilon_{\mathrm{fLu}}$ \\
\hline Average & 19 & 57.0 & 44.5 & 791 & 1.8 \\
\hline Standard deviation & 3 & 12.8 & 13.6 & 319 & 0.5 \\
\hline
\end{tabular}

